\title{
BIBLIOGRAFIJA RADOVA HRVATSKIH AUTORA O OBRAZOVANJU INFORMACIJSKIH STRUČNJAKA
}

\author{
BIBLIOGRAPHY OF CROATIAN AUTHORS \\ ON EDUCATION OF INFORMATION PROFESSIONALS
}

\author{
Jelena Lakuš \\ Odsjek za informacijske znanosti \\ Filozofski fakultet Osijek \\ jlakus@ffos.hr \\ Snježana Stanarević Katavić \\ Odsjek za informacijske znanosti \\ Filozofski fakultet Osijek \\ sstanare@ffos.hr \\ Tomislava Žilić \\ Odsjek za informacijske znanosti \\ Filozofski fakultet Osijek \\ tzilic@ffos.hr
}

UDK / UDC [023.5: 37.013.31]:[026/028::069:: 930.25](01)

Izvorni znanstveni rad / Original scientific paper Primljeno / Received: 10. 10. 2018.

Prihvaćeno / Accepted: 16. 6. 2020.

\section{Sažetak}

Cilj. U radu se donosi bibliografija znanstvenih i stručnih radova hrvatskih autora o obrazovanju informacijskih stručnjaka iz triju grana informacijskih i komunikacijskih znanosti - arhivistike i dokumentalistike, knjižničarstva i muzeologije. Rad ima za cilj dati kvantitativni i kvalitativni uvid u hrvatsku znanstvenu i stručnu produkciju iz navedenoga područja te ukazati na njegovu važnost u etabliranju informacijskih znanosti u nas.

Vjesnik bibliotekara Hrvatske 63, 1-2(2020), 747-778 ISSN 0507-1925 
Metodologija. U svrhu pronalaska relevantnih radova o temi pretraženi su domaći izvori (Hrvatska znanstvena bibliografija, Hrčak - Portal znanstvenih časopisa Republike Hrvatske i katalog Nacionalne i sveučilišne knjižnice Zagreb), strane bibliografske, citatne i baze punog teksta iz područja društvenih znanosti dostupne preko Portala elektroničkih izvora za hrvatsku akademsku i znanstvenu zajednicu te tražilica znanstvene literature Google Scholar. U nastojanju da bibliografija bude što cjelovitija, pretraženi su i popisi literature u nađenim radovima, pa je bibliografija tako rađena i de visu. Učinjena je i kvantitativna i kvalitativna analiza prikupljenih bibliografskih jedinica, kao i njihova analiza prema autorstvu, vrsti radova i jeziku.

Rezultati. Kvantitativna analiza pokazala je da su se prvi radovi pojavili već početkom pedesetih godina 20. stoljeća te da se već tada promišljalo o obrazovanju informacijskih stručnjaka. Taj se interes intenzivirao sredinom osamdesetih godina 20. stoljeća te od tada nije jenjavao već je, štoviše, rastao. Najveći je broj radova objavljen u prvom desetljeću 21. stoljeća. Razloge vjerojatno treba tražiti ne samo u naglom razvoju informacijsko-komunikacijskih tehnologija već i u uvođenju Bolonjskog procesa na hrvatska visoka učilišta, čemu su se nastavni kurikulum i obrazovanje informacijskih stručnjaka trebali prilagoditi. Kvalitativna analiza pokazala je da je toj problematici posvećen najveći broj radova. Više od polovine radova napisano je u suautorstvu dvoje ili više autora, što ukazuje na dobru profesionalnu suradnju hrvatske stručne i znanstvene zajednice koja se bavi problematikom obrazovanja informacijskih stručnjaka. Relativno velik broj radova izloženih na inozemnim skupovima, kao i značajan broj radova na engleskom jeziku, ukazuje na važan doprinos hrvatskih autora razumijevanju te problematike i na globalnoj razini.

Originalnost/Vrijednost. Vrijednost je rada u tome što ovakva tematska bibliografija do sada nije postojala. Rad je ujedno poticaj novim generacijama znanstvenika i stručnjaka na daljnje promišljanje o obrazovanju informacijskih stručnjaka i o nužnosti njihova kontinuiranog stručnog usavršavanja i prilagodbe novim informacijsko-komunikacijskim tehnologijama.

Ključne riječi: arhivisti, bibliografija, Hrvatska, informacijski stručnjaci, informacijske i komunikacijske znanosti, knjižničari, muzealci

\begin{abstract}
Purpose. The paper provides a bibliography of scientific and professional papers of Croatian authors on the education of information professionals in three branches of information and communication sciences: archives and documentation, librarianship, and museology. The aim of the paper is to provide quantitative and qualitative insights into Croatian scientific and professional production in the mentioned areas and to indicate its importance in the establishment of the field of information sciences in Croatia.
\end{abstract}

Methodology. In order to find the relevant papers on the subject the following sources have been searched: the Croatian Scientific Bibliography, Hrčak - Portal of Sci- 
entific Journals of the Republic of Croatia, the catalog of the National and University Library of Zagreb, the bibliographic, citation and full text databases in the field of social sciences available through the Electronic Source Portal for the Croatian Academic and Scientific Community, and finally the Google Scholar search engine. In an effort to keep the bibliography as complete as possible, the lists of literature in the identified works were also searched, and for this reason, the bibliography can be considered to be made de visu. The collected bibliography entries were analyzed from the quantitative and qualitative perspectives as well as by the authorship, types of papers, and language.

Findings. The quantitative analysis showed that the first papers appeared in the early 1950 s, and that even then much thought was given to the education of information professionals. This interest intensified in the mid-1980s and has not faded since then, but rather has grown. The largest number of papers appeared in the first decade of the 21 st century. The reasons should probably be found not only in the rapid development of information and communication technologies but also in the introduction of the Bologna process into the Croatian higher education institutions, and the consequent adaptations and changes that had to be made in the curriculum and education of information professionals. The qualitative analysis has shown that a large number of papers were devoted to this topic. More than half of the papers were co-authored by two or more authors, which indicates good professional cooperation between the members of the Croatian professional and scientific community dealing with the issues of education of information professionals. The fact that a relatively large number of papers was presented at foreign conferences, and that a significant number of papers was written in English, indicate the importance of the contribution of Croatian authors to the understanding of this issue at the global level.

Originality/value. The thematic bibliography of this type has not been made before. The paper is also a stimulus for a new generation of scientists and experts to further explore the topic of education of information professionals who should constantly work on their professional development and learn how to adapt to new information and communication technologies.

Keywords: archivists, bibliography, Croatia, information specialists, information and communication sciences, librarians, museologists

\section{Uvod}

Polje informacijskih znanosti relativno je mlado znanstveno polje, čije začetke možemo tražiti u pedesetim godinama prošloga stoljeća. ${ }^{1}$ Tijekom nekoliko desetljeća svoga postojanja, pod utjecajem novih informacijsko-komunikacijskih

1 Ingwersen, P. Information and information science in context. // Libri 42, 2(1992), str. 101; Aparac-Gazivoda, T. Teorijske osnove knjižnične znanosti. Zagreb: Filozofski fakultet, Zavod za informacijske studije Odsjeka za informacijske znanosti, 1993. Str. 63. 
tehnologija, ono se razvijajući neprestano mijenjalo. U skladu s tim promjenama, nužno su se morale mijenjati i profesionalne kompetencije informacijskih stručnjaka. Obrazovanje informacijskih stručnjaka i prilagodba obrazovnog programa novim izazovima informacijskog doba stoga su od samih početaka, pa i u vrijeme kada formalnog obrazovanja knjižničara, ali i drugih srodnih struka, nije niti bilo, izazivali veliki interes hrvatske stručne i znanstvene zajednice. Rezultat je toga velik broj znanstvenih i stručnih radova koji govore o navedenoj problematici, a koje smo u ovoj bibliografiji nastojali okupiti kako bismo zorno prikazali put, jasno vidljiv iz popisa bibliografskih jedinica, kojim su se knjižničari, ali i drugi informacijski stručnjaci, kretali još od razdoblja neformalnih oblika njihove profesionalne edukacije, preko početaka sustavnog formalnog obrazovanja knjižničara/ informacijskih stručnjaka od druge polovice 1970-ih godina ${ }^{2}$ pa sve do danas, kada se moraju suočavati s brzim razvojem informacijsko-komunikacijske tehnologije te stalno stjecati nova znanja, vještine i kompetencije.

Svjesni već desetljećima prisutne dileme identiteta informacijskih znanosti ${ }^{3}$ te imajući u vidu narav i cilj časopisa Vjesnik bibliotekara Hrvatske, kao i stručne i znanstvene interese njegovih čitatelja, ograničili smo se na znanstvene i stručne radove iz samo nekoliko grana - arhivistike i dokumentalistike, knjižničarstva i muzeologije - inače vrlo šarolikog polja informacijskih i komunikacijskih znanosti. ${ }^{4}$ Radovima uključenima u tu tematsku ili specijalnu bibliografiju zajedničko je bavljenje raznim vidovima obrazovanja i nastavnih programa u navedenim granama informacijskih i komunikacijskih znanosti. Bibliografijom su, međutim, obuhvaćeni samo znanstveni i stručni radovi, dok sažeci u zbornicima skupova, posteri i predavanja nisu uključeni.

2 O obrazovanju knjižničara do sredine 1970-ih godina vidi u: Švenda-Radeljak, K. Obrazovanje i status knjižničara u Hrvatskoj do uvođenja studija bibliotekarstva. Zagreb: Pravni fakultet Sveučilišta, 2018.

3 Vidi, primjerice: Borko, H. Information science: what is it? // American Documentation 19, 1(1968), 3-5. [citirano: 2018-09-29]. Dostupno na: http://jacksonmedeiros.files.wordpress. com/2008/08/information-science-what-is-it.pdf ; Vakkari, P. Library and information science: its content and scope. // Advances in Librarianship 18 (1994), 1-55.; Rayward, W. B. The history and historiography of information science: some reflections. // Information Processing \& Management 32, 1(1996), 3-17. [citirano: 2018-09-29]. Dostupno na: http://citeseerx.ist.psu.edu/viewdoc/download?doi=10.1.1.136.1963\&rep=rep1\&type=pdf; Zins, C. Conceptions of information science. // Journal of the American Society for Information Science and Technology 58, 3(2007), 335-350.; Zins, C. Knowledge map of information science. // Journal of the American Society for Information Science (JASIST) 58, 4(2007), 526-535.

4 Prema Pravilniku o znanstvenim i umjetničkim područjima, poljima i granama iz 2009. godine informacijskim su znanostima obuhvaćene sljedeće grane: arhivistika i dokumentalistika, informacijski sustavi i informatologija, knjižničarstvo, komunikologija, odnosi s javnošću, leksikografija i enciklopedistika, muzeologija, masovni mediji, novinarstvo, organizacija i informatika, informacijsko i programsko inženjerstvo. Usp. Pravilnik o znanstvenim i umjetničkim područjima, poljima i granama. // Narodne novine 118, 2929(2009). [citirano: 2018-09-29]. Dostupno na: https://narodne-novine.nn.hr/clanci/sluzbeni/2009_09_118_2929.html. 
U svrhu izrade što sveobuhvatnije bibliografije odabrani su izvori za koje se na temelju njihova obuhvata autora, radova i znanstvenih područja pretpostavilo da sadrže bibliografske podatke potrebne za izradu ove bibliografije. Odabrani su i pretraženi sljedeći domaći izvori: Hrvatska znanstvena bibliografija (CROSBI), Hrčak - Portal znanstvenih časopisa Republike Hrvatske te katalog Nacionalne i sveučilišne knjižnice Zagreb. Također su pretražene strane baze podataka iz područja društvenih znanosti dostupne preko Portala elektroničkih izvora za hrvatsku akademsku i znanstvenu zajednicu. Pretražene su baze punog teksta dostupne preko platforme baza podataka EBSCOhost (Academic Search Complete, Library, Information Science \& Technology Abstracts i MasterFILE Premier), baza Emerald eJournals Premier, zatim bibliografske i citatne baze podataka dostupne preko platforme baza podataka Web of Science (WoS) i citatne baze SCOPUS. Osim navedenih izvora, pretraživanje je provedeno i u tražilici znanstvene literature Google Scholar.

Navedeni su izvori pretraženi na napredan način prema tehnikama pretraživanja koje podržavaju kao što su skraćivanje riječi, Booleovi operatori, ograničavanje na geografsko podrijetlo autora, ograničavanje na predmetno područje informacijskih i komunikacijskih znanosti i slično. U pretraživanju su korišteni sinonimi i varijantni termini termina iz naslova bibliografije (hrvatski termini obrazovanje: obrazovanje, edukacija, nastava, školovanje; informacijski stručnjaci: informacijski stručnjaci, informacijske znanosti, knjižnična i informacijska znanost, knjižničar, muzeolog, arhivist; engleski termini - obrazovanje: education, training; informacijski stručnjaci: information professional, information science, library and information science, librarian, archivist, museologist).

Premda je cilj ove bibliografije dati sveobuhvatan pregled radova hrvatskih autora o obrazovanju informacijskih stručnjaka, moguće je da su zbog izbora izvora i/ili ključnih riječi u pretraživanju pojedini radovi ostali neuočeni. Kako bismo umanjili vjerojatnost propusta uključivanja relevantnih radova u bibliografiju, dodatno su pregledani popisi literature u nađenim radovima koji su se prema gore pojašnjenim kriterijima našli u ovoj bibliografiji.

U namjeri da pokažemo kontinuirani interes hrvatske stručne i znanstvene javnosti za problematiku obrazovanja informacijskih stručnjaka, odlučili smo se za kronološki bibliografski niz unutar kojega su bibliografske jedinice poredane abecedno prema prezimenu autora.

\section{Bibliografija}

1950.

1. Bendiš, Vjera. Bibliotekarski tečajevi na omladinskoj pruzi Šamac-Sarajevo i na autoputu. // Vjesnik bibliotekara Hrvatske 1, 1/3(1950), 192-193. 
2. Hergešić, Branka. Bibliotekar, njegovo zvanje i školovanje: bilješke s puta. // Vjesnik bibliotekara Hrvatske 1, 1/3(1950), 173-180.

3. $\mathrm{M}[$ išić], J[elka]. Tečaj za bibliotekare naučnih i stručnih knjižnica. // Vjesnik bibliotekara Hrvatske 1, 1/4(1950), 185-186.

4. Radovanović, Milica. O nekim iskustvima u izgradnji knjižničarskog kadra u NR Hrvatskoj. // Vjesnik bibliotekara Hrvatske 1, 1/4(1950), 189-192. 1954.

5. Tečajevi za knjižničare u Hrvatskoj. // Vjesnik bibliotekara Hrvatske 3, 3/4(1954), 142-143.

1957.

6. Seminar za knjižničare. // Vjesnik bibliotekara Hrvatske 4, 1/4(1955-1957), 173-175.

1958.

7. Ljetni seminar za knjižničare na Cresu. // Vjesnik bibliotekara Hrvatske 5, 1/4(1958-1959), 144-145.

8. Rojnić, Matko. Stručno obrazovanje bibliotekara. // Drugi i treći kongres Saveza društava bibliotekara FNR Jugoslavije. Ljubljana, 1958. 1960.

9. Malnar, Aleksandra. Školovanje knjižničara. // Vjesnik bibliotekara Hrvatske 6, 3/4(1960), 84-95.

1961.

10. Ljetni seminari za bibliotekarsko osoblje. // Vjesnik bibliotekara Hrvatske 7, 3/4(1961), 230.

1962.

11. Vuković, Višnja. Seminar za knjižničare i bibliotekare. // Vjesnik bibliotekara Hrvatske 8, 3/4(1962), 185-186.

1963.

12. Hećimović, V. Seminar za knjižničare učeničkih knjižnica u eksperimentalnim osnovnim školama. // Vjesnik bibliotekara Hrvatske 9, 1/2(1963), 71.

13. Vuković, Višnja. Seminar za knjižničare. // Vjesnik bibliotekara Hrvatske 9, 1/2(1963), 70.

14. Vuković, Višnja. Seminar za školske knjižničare Zagreba. // Vjesnik bibliotekara Hrvatske 9, 1/2(1963), 70. 
1964.

15. Vuković, Višnja. Seminar za bibliotekare. // Vjesnik bibliotekara Hrvatske 10, 3/4 (1964), 139-140.

1965.

16. Blažeković, Tatjana. Kolegij bibliotekarstva na Pedagoškoj akademiji u Rijeci. // Vjesnik bibliotekara Hrvatske 11, 1/2(1965), 67-68.

17. B[lažeković], T[atjana]. Tečaj za bibliotekare i knjižničare naučnih i specijalnih bibliotekara Hrvatske. // Vjesnik bibliotekara Hrvatske 11, 1/4(1965), 148-149.

18. Seminar za bibliotekare. // Vjesnik bibliotekara Hrvatske 11, 3/4(1965), 139140.

19. Vuković, Višnja. Tečaj za knjižničare. // Vjesnik bibliotekara Hrvatske 11, 3/4(1965), 149.

20. V.[uković], V[išnja]. Tečaj za knjižničare i bibliotekare. // Vjesnik bibliotekara Hrvatske 12, 3/4(1966), 144-145.

1967.

21. Vuković, Višnja. Seminar za bibliotekare srednjih škola. // Vjesnik bibliotekara Hrvatske 13, 3/4(1967), 142-143.

1968.

22. Blažeković, Tatjana. Prikaz školovanja knjižničarskog kadra na Pedagoškoj akademiji u Rijeci. // Vjesnik bibliotekara Hrvatske 14, 3/4(1968), 280-284.

23. Seminari za bibliotekare i knjižničare. // Vjesnik bibliotekara Hrvatske 14, 3/4(1968), 87-88.

24. Šperac, Julka. Seminari za knjižničare osnovnih škola. // Vjesnik bibliotekara Hrvatske 14, 3/4(1968), 284-286.

1969.

25. Furlan, Branka; Nevenka Košutić-Brozović; Vanda Milčetić. Kolegij o osnovama bibliotekarstva na pedagoškim akademijama u Hrvatskoj. // Vjesnik bibliotekara Hrvatske 15, 3/4(1969), 165-168.

26. Seminari za bibliotekare i knjižničare početnike u Puli. // Vjesnik bibliotekara Hrvatske 15, 3/4(1969), 168-169.

1970.

27. Furlan, Branka. Seminar za školske knjižničare u Pazinu. // Vjesnik bibliotekara Hrvatske 16, 1/2(1970), 54. 
28. Mikačić, Mira. O obrazovanju radnika u bibliotekarskoj struci u Hrvatskoj. // Vjesnik bibliotekara Hrvatske 16, 3/4(1970), 103-116. 1971.

29. Mikačić, Mira. Školovanje bibliotečnih radnika u SFR Jugoslaviji. // Bibliotekar 33, 6(1971), 753-762. 1974.

30. Mikačić, Mira. Izvještaj Komisije za školovanje i obrazovanje kadrova. // Peta skupština Saveza društava bibliotekara Jugoslavije, Beograd, 26.-28. Septembar 1973. Beograd: Savez društava bibliotekara Jugoslavije, 1974. Str. 119-121. 1976.

31. Blažeković, Tatjana. Teorija i praksa osposobljavanja školskog knjižničara. // Radovi Pedagoške akademije u Rijeci 4 (1976), 23-30. 1978.

32. Markić-Čučković, Ljerka. U povodu uvođenja studija bibliotekarstva na Filozofskom fakultetu Sveučilišta u Zagrebu. // Vjesnik bibliotekara Hrvatske 23, 1/4(1977-1978), 147-150.

33. Mikačić, Mira. Školovanje bibliotekara. // Vjesnik bibliotekara Hrvatske 23, 1/4(1977-1978), 85-88.

1980.

34. Blažeković, Tatjana. Školovanje viših knjižničara na Pedagoškoj akademiji u Rijeci od školske godine 1964./65. od školske godine 1977./1978. // Vjesnik bibliotekara Hrvatske 24, 1/4(1979-1980), 95-102.

1981.

35. Berčič, Branko; Matko Rojnić. Bibliotekarsko strokovno izobraževanje in mi: aktualno spominsko razmišljanje. // Vjesnik bibliotekara Hrvatske 1, 1/4(1981), 11-18.

1982.

36. Vicić, Snježana. Pretpostavke, sadržaj i značaj stručnih ispita u procesu stručnog obrazovanja bibliotečnih radnika u Hrvatskoj (1951-1981). // Vjesnik bibliotekara Hrvatske 26, 1/4(1982), 1-29. 
1983.

37. Maroević, Ivo. Muzeološko obrazovanje muzejskih radnika. // Informatica museologica 14, 1/2(1983), 3-5. [citirano: 2018-10-02]. Dostupno na: https:// hrcak.srce.hr/145895

1984.

38. Markić-Čučuković, Ljerka. Međunarodna konferencija o obrazovanju u bibliotečnoj i informacijskoj znanosti, Dubrovnik, 21.-25. svibnja 1984. // Vjesnik bibliotekara Hrvatske 27, 1/4(1983-1984), 122-125.

39. Maroević, Ivo. Predmet muzeologije u okviru teorijske jezgre informacijskih znanosti. // Informatica museologica 15, 1/3(1984), 3-6. [citirano: 2018-1002]. Dostupno na: https://hrcak.srce.hr/145747

1985.

40. Aparac-Gazivoda, Tatjana; Aleksandra Horvat. Dodiplomsko obrazovanje bibliotečnih i ostalih informacijskih stručnjaka. // Obrazovanje za tehnološki razvoj: savjetovanje. Zagreb: Savez inženjera i tehničara, 1985. Str. 181-188. 1986.

41. Aparac-Gazivoda, Tatjana. Četverogodišnji studij informacijskih znanosti na Filozofskom fakultetu u Zagrebu. // Obrazovanje bibliotekara na dodiplomskoj razini: Radovi II interkatedarskog skupa nastavnika bibliotekarstva, Zagreb, 17.-18. siječnja 1986. Zagreb: Hrvatsko bibliotekarsko društvo, 1986. Str. 35-37.

42. Aparac-Gazivoda, Tatjana. Uvođenje novih sadržaja u nastavu bibliotekarstva. // Četvrto jugoslavensko savjetovanje o primjeni računara u bibliotekama, Sarajevo, 9.-11. travnja 1986. Sarajevo: Narodna i univerzitetska biblioteka BiH, 1986. Str. 179-183.

43. Markić-Čučković, Ljerka. Pokušaji koordinacije programa studija bibliotekarstva (s osvrtom na Veliku Britaniju). (2. Interkatedarski skup o obrazovanju bibliotekara na dodiplomskoj razini, Zagreb, 17.-18. 1. 1986.). // Vjesnik bibliotekara Hrvatske 29, 1/4(1986), 1-17.

1987.

44. Aparac-Gazivoda, Tatjana; Biserka Dunda; Aleksandra Malnar; Đurđa Mesić; Dubravka Stančin-Rošić. Bibliotekarski kadrovi, stručnost i obrazovanje kao pretpostavke za daljnji razvoj bibliotečne djelatnosti u SRH: polazišta za raspravu. // Vjesnik bibliotekara Hrvatske 30, 1(1987), 133-153. 
1988.

45. Aparac-Gazivoda, Tatjana. Drugi interkatedarski skup o obrazovanju bibliotekara na dodiplomskoj razini, Zagreb, 17.-18. siječnja 1986. // Vjesnik bibliotekara Hrvatske 29, 1/4(1988), 117-119.

1994.

46. Horvat, Aleksandra; Marija László. Obrazovanje knjižničara za osnivanje, obnovu i vođenje knjižničnih zbirki. // Vjesnik bibliotekara Hrvatske 37, 3/4(1994), 37-48.

47. Lasić-Lazić, Jadranka. Obrazovanje školskih knjižničara. // Zbornik radova 5. Proljetne škole školskih knjižničara Republike Hrvatske / uredila Višnja Šeta. Rijeka: Ministarstvo prosvjete, kulture i športa, Zavod za školstvo Republike Hrvatske, 1994. Str. 105-109.

1996.

48. Aparac, Tatjana; Aleksandra Malnar; Dubravka Stančin-Rošić. Stalno stručno usavršavanje knjižničarskog osoblja u Republici Hrvatskoj: potrebe i mogućnosti. // Vjesnik bibliotekara Hrvatske 39, 1/2(1996), 207-223.

49. Horvat, Aleksandra. Školovanje knjižničara u Hrvatskoj. // Vjesnik bibliotekara Hrvatske 39, 1/2(1996), 133-142.

50. Erl, Vera; Kornelija Petr. Studij bibliotekarstva na Pedagoškom fakultetu u Osijeku: da ili ne?. // Vjesnik bibliotekara Hrvatske 39, 1/2(1996), 163-170.

51. Lasić-Lazić, Jadranka. Suvremena kretanja u obrazovanju i obrazovanje informacijskih stručnjaka. // Vjesnik bibliotekara 39, 1/2(1996), 241-246.

52. Mikačić, Mira. Bibliotekarska djelatnost i bibliotečna znanost: obrazovanje za rad i obrazovanje za razvoj djelatnosti. // Vjesnik bibliotekara Hrvatske 39, 1/2(1996), 143-156.

53. Radman, Ljuba. Osvrt na školovanje knjižničara u Osijeku od 1977. do 1990. godine. // Vjesnik bibliotekara Hrvatske 39, 1/2(1996), 157-161.

54. Slavić, Aida. Istraživanje potreba diplomiranih bibliotekara za dodatnim obrazovanjem i usavršavanjem u području informacijskih tehnologija. // Vjesnik bibliotekara Hrvatske 39, 1/2(1996), 253-264.

1997.

55. Aparac, Tatjana. Continuing education for Croatian librarians: needs and opportunities. // Human development: competencies for the twenty-first century: papers from the IFLA CPERT Third International Conference on Continuing Professional Education for the Library and Information Professions / uredile Patricia Layzell Ward i Darlene E. Wiengand. Muenchen: Saur, 1997. Str. 271-277. 
56. Aparac, Tatjana; Aida Slavić. The students' attitude towards the use of information technologies in the teaching process. // Proceedings of the 5th international BOBCATSSS symposium / uredio S. Van Bergen. Amsterdam: Hogeschool van Amsterdam, 1997. Str. 313-314.

57. Aparac, Tatjana. Biti bibliotekar: jučer, danas, sutra. // Knjižnica 41, 2(1997), 33-44. [citirano: 2018-10-02]. Dostupno na: http://www.ffzg.unizg.hr/infoz/ dzs/text/bbjds.pdf

58. Horvat, Aleksandra. Školovanje i izobrazba bibliotekara pred novim tisućljećem. // Vjesnik bibliotekara Hrvatske 40, 1/2(1997), 131-138.

59. Ivanović, Jozo. Modeli obrazovanja arhivista. // Arhivski vjesnik 40, 1(1997), 15-34. [citirano: 2018-10-02]. Dostupno na: https:/hrcak.srce.hr/11052

60. Kolanović, Josip. Identitet arhivista: od zanimanja do profesije. // Arhivski vjesnik 40 (1997), 7-14. [citirano: 2018-10-02]. Dostupno na: https://hrcak. srce.hr/11047

61. Lasić-Lazić, Jadranka; Radovan Vrana. Nestaje li knjižničarska struka?. // Knjižnica 41, 2/3(1997), 237-250. [citirano: 2018-10-02]. Dostupno na: https://core.ac.uk/download/pdf/25960835.pdf

62. Maroević, Ivo. University training in museology: the University of Zagreb's experience. // ISSOM, Proceedings of the international symposium "Museology for tomorrow's world" / uredio Zbyněk Zbyslav Stransky. Munich: Verlag Dr. Christian Mueller-Straten, 1997. Str. 126-130.

63. Pandžić, Miljenko. Obrazovanje arhivista: usporedni pregled školovanja u raznim zemljama svijeta. / Arhivski vjesnik 40 (1997), 35-42. [citirano: 2018-10-02]. Dostupno na: https://hrcak.srce.hr/11057

64. Rastić, Marijan. Oblici izobrazbe arhivista u Hrvatskoj. / Arhivski vjesnik 40 (1997), 43-55. [citirano: 2018-10-02]. Dostupno na: https://hrcak.srce. $\mathrm{hr} / 11063$

65. Rubčić, Darko. Obrazovanje djelatnika u pismohranama: regulativa i praksa. // Arhivski vjesnik 40 (1997), 57-62. [citirano: 2018-10-02]. Dostupno na: https://hrcak.srce.hr/11064

1998.

66. Horvat, Aleksandra. Zajedničko i posebno u stručnoj naobrazbi bibliotekara, arhivista i muzeologa. // Arhivi, knjižnice, muzeji: mogućnosti suradnje u okruženju globalne informacijske infrastrukture / uredile Mirna Willer i Tinka Katić. Zagreb: Hrvatsko bibliotekarsko društvo, 1998. Str. 29-37.

67. Lasić-Lazić, Jadranka. Doprinos Bože Težaka obrazovanju informacijskih stručnjaka i bibliotekara. // Informatologia 31, 3/4(1998), 131-133. [citirano: 2018-10-02]. Dostupno na: https://hrcak.srce.hr/file/198059 
68. Lasić-Lazić, Jadranka; Aida Slavić. Obrazovanje knjižničara za 21. stoljeće: zajednička briga onih koji obrazuju i onih koji zapošljavanju. // Godišnjak Gradske knjižnice i čitaonice „Metel Ožegović“" Varaždin 2 (1998), 122-132.

69. Lasić-Lazić, Jadranka; Aida Slavić. How to adapt a traditional LIS education curricula to new needs of knowledge organisation : example of the course „Library classification and classification systems“. // Shaping the knowledge society: proceedings of the 6th International BOBCATSSS-Symposium / uredili Camilla Moring, Anders Christiansen i Nanna Kann-Rasmussen. Copenhagen: Royal School of Library and Information Science, 1998. Str. 224-237.

70. Maroević, Ivo. Museological study courses at the University of Zagreb, Croatia. // Museum Aktuell 31 (1998), 1036-1037.

1999.

71. Erl, Vera. Školovanje knjižničara u Hrvatskoj. // Život i škola 45, 1-2(1999), 39-59.

72. Horvat, Aleksandra. Library legislation and free access to information as new topics in LIS education. // Informacijos mokslai 11/12 (1999), 131-136. [citirano: 2018-10-02]. Dostupno na: http://www.informationr.net/ir/5-2/paper72.html

73. Horvat, Aleksandra. Obrazovanie i vospituvanje bibliotekari na početokot na noviot vek. // Bibliotekarska iskra 17, 1/2(1999), 37-41.

74. Lasić-Lazić, Jadranka. Kako obrazovati knjižničara za rad u 21. stoljeću. // Školska knjižnica u 21. stoljeću: zbornik radova 10. proljetne škole školskih knjižničara / uredila Višnja Šeta. Rijeka: Ministarstvo prosvjete, kulture i športa, Prva sušačka hrvatska gimnazija u Rijeci, 1999. Str. 3-11.

75. Lasić-Lazić, Jadranka; Aida Slavić. Profesionalno obrazovanje knjižničara: teorijska uporišta i praktični problemi. // Knjižnica 43, 2/3(1999), 95-111.

76. Tkalac, Slavko; Jadranka Lasić-Lazić; Aida Slavić; Nikolaj Lazić; Kristina Vučković. Education of information professionals - Croatian perspective. // Learning society, learning organisation, lifelong learning: proceedings of the 7th International BOBCATSSS-Symposium / uredila Sandra Beheim [et. al.]. Darmstadt: BOBCATSSS Organisation Team, 1999. Str. 468-474.

2000.

77. Aparac, Tatjana. Informacijske znanosti: temeljni koncepti i problemi. // Seminar Arhivi, knjižnice, muzeji / uredile Mirna Willer i Tinka Katić. Zagreb: Hrvatsko bibliotekarsko društvo, 2000. Str. 37-48.

78. Horvat, Aleksandra. Library legislation and free access to information as new topics in LIS education. // Information Research 5, 2(2000). [citirano: 
2018-10-02]. Dostupno na: http://www.informationr.net/ir/5-2/paper72. html

79. Lasić-Lazić, Jadranka; Aida Slavić. Obrazovanje školskih knjižničara kao teorijsko i praktično pitanje. // Školska baština: zbornik radova 11. Proljetne škole školskih knjižničara Republike Hrvatske / uredila Višnja Šeta. Rijeka : Ministarstvo prosvjete, kulture i športa; Prva sušačka hrvatska gimnazija, 2000. Str. 101-111.

80. Lasić-Lazić, Jadranka; Aida Slavić. Školovanje knjižničara: kako prilagoditi „tradicionalne“ programe „novom vremenu“ i promijenjenim zadaćama. // Vjesnik bibliotekara Hrvatske 43, 4(2000), 59-69.

81. Lasić-Lazić, Jadranka; Aida Slavić. Organization and management of information professionals' education. // Informatologia 33, 3/4(2000), 198-202.

2001.

82. Aparac, Tatjana; Radovan Vrana; Boris Badurina; Martina Dragija. How the graduate LIS professionals cope with constant need for updating their knowledge and skills: a Croatian case. // Proceedings of the Fourth World Conference on Continuing Professional Education for the Library and Information Professions: An IFLA Pre-conference / uredile Blanche Woolls i Brooke E. Sheldon. Muenchen: Saur, 2001. Str. 164-172.

83. Lasić-Lazić, Jadranka. Uloga i razvoj sadržajne obrade u kurikulumu knjižničarstva i informacijske znanosti Sveučilišta u Zagrebu. // Vjesnik bibliotekara Hrvatske 44, 1/4 (2001), 188-199.

84. Lasić-Lazić, Jadranka; Aida Slavić; Hrvoje Stančić. Educating information professionals. // Proceedings of the 9th International BOBCATSSS Symposium on Library and Information Science: Knowledge, Information and Democracy in the Open Society: the Role of the Library and Information Sector. Vilnius, 2001. Str. 214-219.

85. Lučić, Melina. Obrazovanje arhivista i spisovoditelja za novo okruženje: praksa u svijetu i izgledi u Hrvatskoj. // Arhivski vjesnik 44 (2001), 33-42. [citirano: 2018-10-02]. Dostupno na: https://hrcak.srce.hr/9307

2002.

86. Afrić, Vjekoslav; Jadranka Lasić-Lazić; Boris Badurina; Martina Dragija Ivanović; Koraljka Golub. Qualifications of information specialists: case of library and information students at the Department of Information Science, Faculty of Philosophy, University of Zagreb, Croatia. // International 5 Symposium on Library and Information Science: Human Beings and Information Specialists: future skills, qualifications, positioning (BOBCATSSS 2002): proceedings / uredili Branka Badovinac [et. al.]. Ljubljana; Stuttgart: Faculty of Arts, Department of Library and Information 
Science and Book Studies; University of Applied Sciences, 2002. Str. 232240. [citirano: 2018-10-02]. Dostupno na: http://koraljka.info/publ/2002BOBCATSS.pdf

87. Horvat, Aleksandra. Fragmentation of LIS curriculum: is it permanent or transient?. // Restructuring and adapting LIS education to European standards: overcoming regional variations in needs and interests in education for LIS: proceedings of a EUCLID conference Thessaloniki, Greece, October 2002. Str. 1-7.

88. Lasić-Lazić, Jadranka; Aida Slavić. Obrazovanje informacijskih stručnjaka za globalni informacijski prostor. // Zbornik radova "Težakovi dani" / uredili Jadranka Lasić-Lazić i Slavko Tkalec. Zagreb: Filozofski fakultet, Zavod za informacijske studije Odsjeka za informacijske znanosti, 2002. Str. 151-158.

89. Lasić-Lazić, Jadranka; Aida Slavić. Who will organize information and who will manage it? Education of information professionals at the University of Zagreb. // Proceedings of the International Meeting / uredile Aleksandra Vranješ i Ljiljana Marković. Beograd: Faculty of Philosophy of Belgrade University, National Library of Serbia, 2002. Str. 123-135.

90. Lasić-Lazić, Jadranka; Aida Slavić. Obrazovanje: kako unaprijediti djelotvornost i kvalitetu. // Informatologia 35, 3(2002), 198-202.

91. Petr, Kornelija; Radovan Vrana; Tatjana Aparac-Jelušić. Obrazovanje na daljinu: mogući model u području knjižnične i informacijske znanosti Hrvatske. // Edupoint 2, 2(2002), 1-9. [citirano: 2018-10-02]. Dostupno na: http:// edupoint.carnet.hr/casopis/broj-02/clanak-03/moguci_model.pdf

92. Petr, Kornelija; Radovan Vrana; Tatjana Aparac. Web based LIS education: potentials and feasibility of regional models. // Continuing professional education for the information society: the Fifth world conference on professional education for the library and information science professionals / uredila Patricia Layzell Ward. Munchen : Saur, 2002. Str. 205-213.

2003.

93. Aparac-Jelušić, Tatjana; Kornelija Petr. Web based Training for LIS students in Croatia: goals and pilot projects. // Pedagógial informació határok nélkúl / uredila Zsuzsanna Zeller. Budimpešta: Országos Pedagogial Könyvtár és Museum, 2003. Str. 52-65.

94. Faletar, Sanjica; Martina Dragija-Ivanović; Tatjana Aparac-Jelušić. Obrazovni programi u području informacijskih znanosti u odnosu na potrebe AKM zajednice. // 6. seminar Arhivi, knjižnice, muzeji: mogućnosti suradnje u okruženju globalne informacijske infrastrukture: zbornik radova / uredila Tinka Katić. Zagreb: Hrvatsko knjižničarsko društvo, 2003. Str. 168-188. 
95. Horvat, Aleksandra. Fragmentation of the LIS curriculum: the case of Croatia. // New Library World 104, 6(2003), 227-232. DOI: https://doi. org/10.1108/03074800310481911

96. Lasić-Lazić, Jadranka; Aida Slavić; Mihaela Banek Zorica. Curriculum development in the field of information science: knowledge organization courses. // Computers in education: proceedings of the Conference $\mathrm{CE}=$ Računala $\mathrm{u}$ obrazovanju: zbornik radova Savjetovanja CE; u okviru XXVI. međunarodnog skupa MIPRO 2003. = XXVI. International Convention MIPRO 2003 / uredili Marina Čičin-Šain, Pavle Dragojlović i Ivana Turčić Prstačić. Rijeka: Hrvatska udruga za mikroprocesorske, procesne i informacijske sustave, mikroelektroniku i elektroniku - MIPRO HR, 2003. Str. 116-122. [citirano: 201810-02]. Dostupno na: http://www.ffzg.unizg.hr/infoz/tempus/mipro2003.pdf

97. Maroević, Ivo. Muzeološko školovanje u Hrvatskoj - važnost, razvitak i posljedice (Trebala je trećina stoljeća da se od poslijediplomskog dođe do široke skale muzeoloških obrazovnih programa). // Informatica museologica 34, 1/2(2003), 6-12. [citirano: 2018-10-02]. Dostupno na: https://hrcak.srce. $\mathrm{hr} / 140443$

98. Vujić, Žarka. Akademsko obrazovanje za muzejsku profesiju u Hrvatskoj danas: između potpore akademske zajednice i jačanja krhkog odnosa prema onoj muzejskoj. // Informatica museologica 34, 1/2(2003), 13-16. [citirano: 2018-10-02]. Dostupno na: https://hrcak.srce.hr/140444

2004.

99. Aparac-Jelušić, Tatjana. Obrazovanje na daljinu i podrška knjižnica. // Edupoint: časopis o primjeni informacijskih tehnologija u obrazovanju 4, 29(2004). [citirano: 2018-09-15]. Dostupno na: http://edupoint.carnet.hr/casopis/29/clanci/1.html

100. Aparac-Jelušić, Tatjana. Mobilnost studenata knjižnične i informacijske znanosti. // Organizacija znanja 3 (2004), 130-133.

101. Aparac-Jelušić, Tatjana. Distance Education in the LIS field: possibilities and limitations observed through experience. // Vloga specialnih in visokošolskih knjižnic v procesu evropske integracije / uredili A. Rožić-Hristovski i K. Hacin-Ludvig. Ljubljana: Sveza bibliotekarskih društev Slovenije, 2004. Str. 3-11.

102. Erl, Vera. Obrazovanje knjižničara u Hrvatskoj: studij knjžničarstva Osijek= Könyvtárosok képzése horvátországban : könyvtártudományi tanulmányok Eszéken. // Knjižničarstvo 8, 1(2004), 57-83.

103. Horvat, Aleksandra. Continuing education of librarians in Croatia: problems and prospects. // New Library World 105, 9/10(2004), 370-375. DOI: https:// doi.org/10.1108/03074800410557321 
104. Lasić-Lazić, Jadranka; Aida Slavić; Mihaela Banek Zorica. Razvoj kurikuluma iz predmeta organizacije znanja. // Odabrana poglavlja iz organizacije znanja / uredila Jadranka Lasić-Lazić. Zagreb: Filozofski fakultet, Zavod za informacijske studije Odsjeka za informacijske znanosti, 2004. Str. 129-141.

105. Lasić-Lazić, Jadranka; Aida Slavić; Mihaela Banek. Gemeinsame Ausbildung der IT-Spezialisten auf der Universität Zagreb: Vorteile und Probleme. // Proceedings der 7. Tagung der Deutsche Sektion der Internationalen Gesellschaft fuer Wissensorganisation / uredili Cristoph Lehner, H. Peter Ohly i Gerhard Rahmstorf. Wuerzburg: Ergon Verlag, 2004. Str. 76-85. [citirano: 2018-1002]. Dostupno na: http://www.isko-de.org/data/uploads/banek00.pdf

106. Lazzarich, Lea. Kontinuirana edukacija informacijskih stručnjaka ili možete li dobiti posao. // Edukacija korisnika i knjižničnog osoblja: zbornik radova / 5. dani specijalnog knjižničarstva Hrvatske, Opatija, 10. i 11. travnja 2003. Zagreb: Hrvatsko knjižničarsko društvo, 2004. Str. 56-64.

2005.

107. Aparac-Jelušić, Tatjana. Bolonjski proces i studij informacijskih znanosti. // Informacijski viri in storitve knjižnic v elektronskem okolju: zbornik referatov, strokovno posvetovanje Zveze bibliotekarskih društev Slovenije / uredila Melita Ambrožič. Ljubljana: Zveza bibliotekarskih društev Slovenije, 2005. Str. 291-306.

108. Aparac-Jelušić, Tatjana; Martina Dragija-Ivanović; Sanjica Faletar; Franjo Pehar. LIS programs reflecting the needs of ALM community: a preliminary research report. // Coping with continual change - change management in SLIS / uredila Linda Ashcroft. Bradford: Emerald, 2005. Str. 46-58.

109. Horvat, Aleksandra. Školovanje knjižničara u svjetlu europskih normi. // Vjesnik bibliotekara hrvatske 48, 1(2005), 1-12. [citirano: 2018-10-02]. Dostupno na: http://www.hkdrustvo.hr/vbh-arhiva/broj/89

110. Lasić-Lazić, Jadranka; Vladimir Mateljan. Educating information professionals. // Informatika, obrazovna tehnologija i novi mediji u obrazovanju: zbornik radova - knjiga 1 / uredio Đorđe Nadrljanski. Sombor: Učiteljski fakultet u Somboru, Centar za izdavačku delatnost, 2005. Str. 118-124.

111. Lazzarich, Lea; Evgenia Popović. Online tečajevi za knjižničare kao oblik cjeloživotnog učenja. // Vjesnik bibliotekara Hrvatske 48, 1(2005), 56-64. [citirano: 2018-10-02]. Dostupno na: http://www.hkdrustvo.hr/vbh-arhiva/ broj/89

112. Lovrinčević, Jasmina; Dinka Kovačević; Jadranka Lasić-Lazić; Mihaela Banek Zorica. Znanjem do znanja: prilog metodici rada školskog knjižničara. Zagreb: Zavod za informacijske studije Odsjeka za informacijske znanosti Filozofskog fakulteta Sveučilišta u Zagrebu, 2005. 
2007.

113. Aparac-Jelušić, Tatjana; Sanjica Faletar Tanacković; Srećko Jelušić. Školovanje arhivista, knjižničara i muzeologa: pogled iz perspektive akademske ustanove. // Radovi s 41. savjetovanja Arhivska služba na pragu pristupa Europskoj Uniji / uredila Deana Kovačec. Zagreb: Hrvatsko arhivističko društvo, 2007. Str. 147-154.

114. Horvat, Aleksandra. Knjižničarski studiji u Hrvatskoj. // Slobodan pristup informacijama: 4. i 5. okrugli stol: zbornik radova / uredile Alemka Belan-Simić i Aleksandra Horvat. Zagreb: Hrvatsko knjižničarsko društvo, 2007. Str. 81-86.

115. Lasić-Lazić, Jadranka; Marija László; Bulcsú László. Konceptualna i primijenjena okosnica studija informacijskih znanosti na Filozofskome fakultetu Sveučilišta u Zagrebu. // InFuture2007: digital information and heritage / uredili Sanja Seljan i Hrvoje Stančić. Zagreb: Odsjek za informacijske znanosti, Filozofski fakultet, Sveučilište u Zagrebu, 2007. Str. 587-592. [citirano: 2018-10-02]. Dostupno na: http://infoz.ffzg.hr/INFuture/2007/PDF/ INFuture2007.pdf

2008.

116. Aparac-Jelušić, Tatjana. New LIS, IS and publishing programs in Croatia. // IFLA SET Bulletin 9, 1(2008), 17-20.

117. Petr, Kornelija. Education for cataloguing and classification at the Department of Information Sciences in Osijek, Croatia. // Cataloging \& Classification Quarterly 45, 4 (2008), 25-42.

2009.

118. Barbarić, Ana. Knjižničarske kompetencije. // Cjeloživotno učenje knjižničara: ishodi učenja i fleksibilnost / uredili Aleksandra Horvat i Dijana Machala. Zagreb: Nacionalna i sveučilišna knjižnica, 2009. Str. 57-68. [citirano: 2018-10-02]. Dostupno na: http://www.nsk.hr/cuk/cuk.pdf

119. Kajberg, Leif; Aleksandra Horvat; Esin Sultan Oğuz. LIS education. // Global library and information science: a textbook for students and educators / uredio Ismaïl Abdullahi. Berlin; New York, de Gruyter: K.G. Saur, 2009. Str. 343-363.

120. Machala, Dijana. Knjižničarske kompetencije i trajna izobrazba knjižničara u Hrvatskoj: iz perspektive dionika na tržištu rada (poslodavaca i knjižničara). // Cjeloživotno učenje knjižničara: ishodi učenja i fleksibilnost / uredili Aleksandra Horvat i Dijana Machala. Zagreb: Nacionalna i sveučilišna knjižnica, 2009. Str. 83-124. [citirano: 2018-10-02]. Dostupno na: http://www.nsk.hr/ cuk/cuk.pdf 
121. Machala, Dijana. E-portfolio for recognition of prior learning assessment in continuing education for librarians in Croatia. // The future of information sciences: INFuture 2009 - Digital resources and knowledge sharing: [2nd international conference], Zagreb, 4-6 November 2009. / uredio Hrvoje Stančić. Zagreb: Department of Information Science, Faculty of Humanities and Social Science, University of Zagreb, 2009. Str. 565-575. [citirano: 201810-02]. Dostupno na: https://infoz.ffzg.hr/infuture/2009/papers/6-07\%20 Machala,\%20D.,\%20E-portfolio\%20for\%20Recognition\%20of\%20 Prior\%20Learning\%20Assessment.pdf

122. Machala, Dijana; Lobel Machala. Ishodi učenja - osiguranje kvalitete stalnog stručnog usavršavanja knjižničara. // Uspostava kvalitete u specijalnim i visokoškolskim knjižnicama - knjižnice u bolonjskom okruženju: zbornik radova / 10. dani specijalnih i visokoškolskih knjižnica, Opatija, 24.-26. travnja 2008. / uredile Alisa Martek i Irena Pilaš. Zagreb : Hrvatsko knjižničarsko društvo, 2009. Str. 24-36.

123. Machala, Dijana; Aleksandra Horvat. Nacionalni program trajne izobrazbe knjižničara utemeljen na ishodima učenja: prema priznavanju neformalnog obrazovanja knjižničara. // Neformalno obrazovanje i informalno učenje odraslih: zbornik radova 4. međunarodne konferencije Neformalno obrazovanje i informalno učenje odraslih održane u Šibeniku 29. - 31. 5. 2009. = Non-formal adult education and informal adult learning: book of proceedings of the international conference, (Šibenik, 29-31 May, 2009) / uredili Milan Matijević i Tihomir Žiljak. Zagreb: Hrvatsko andragoško društvo, 2009. Str. 259-269. [citirano: 2018-10-02]. Dostupno na: http://www.nsk.hr/cuk/cuk.pdf

124. Petr Balog, Kornelija; Ivana Martinović. Na tragu ishoda učenja: kompetencije diplomiranih knjižničara Odsjeka za informacijske znanosti u Osijeku. // Vjesnik bibliotekara Hrvatske 52, 1/4(2009), 1-17. [citirano: 2018-10-02]. Dostupno na: https://hrcak.srce.hr/83011

125. Stančić, Hrvoje. Analiza strukture dodiplomskega, diplomskega in doktorskega študija informacijskih znanosti na Filozofski fakulteti v Zagrebu s poudarkom na arhivistiki. // Izobražavanje arhivskih delavcev in zaposlenih pri ustvarajalcih arhivskega gradiva; Arhivski depoji; Elektronsko arhiviranje in informatizacija v arhivih / uredila Maja Gombač. Dolenjske Toplice: Arhivsko društvo Slovenije, 2009. Str. 35-39.

2010.

126. Cvrković, Jelena. Cjeloživotno obrazovanje školskog knjižničara. // Vukovarsko-srijemski učitelj: godišnjak za teoriju i praksu odgoja i obrazovanja 7(2010), 253-255.

127. Lasić-Lazić, Jadranka; Mihaela Banek Zorica; Sonja Špiranec. Školovanje bibliotekara u Hrvatskoj : strukturne i sadržajne odrednice. // Pančevačko čitalište 9, 17(2010), 6-10. 
128. Lovrinčević, Jasmina; Dinka Kovačević; Zdenka Barišić. Nove možnosti izobraževanja in doseganja ožjih kompetenc. // Kompetence šolskega knjižničarja - zmožnosti, priložnosti, izzivi. Ljubljana, 2010. Str. 208-215.

129. Machala, Dijana. Knjižničarske kompetencije i očekivani ishodi učenja. // XXII. proljetna škola školskih knjižničara Republike Hrvatske, Zagreb, 7.-10. travnja 2010.: zbornik radova / uredio Miroslav Mićanović. Zagreb: Agencija za odgoj i obrazovanje, 2010. Str. 43-49. [citirano: 2018-10-02]. Dostupno na: https://www.azoo.hr/images/izdanja/22_Proljetna_skola_ knjiznicara2010.pdf

130. Machala, Dijana; Aleksandra Horvat. Competency-based lifelong learning of librarians in Croatia: an integrative approach. // EUCLID conferences: cooperation and collaboration in teaching and research: trends in library and information studies education / uredile Anna Maria Tammaro i Gillian Hallam. Borås: European Association for Library \& Information Education and Research, 2010. Str. 1-12.

2011.

131. Hasenay, Damir; Maja Krtalić; Zrinka Šimunić. Obrazovanje studenata informatologije o čuvanju i zaštiti kulturne baštine: temeljna znanja i njihov prijenos u praksu. // Život i škola 57, 25(2011), 61-75. [citirano: 2018-1002]. Dostupno na: https://hrcak.srce.hr/71624

132. Tot, Marko; Daniela Živković. The role of e-learning in LIS education: students〉 evaluations. // Computers in education: proceedings = Računala $u$ obrazovanju: zbornik radova / uredila Marina Čičin-Šain. Rijeka: MIPRO, 2011. Str. 263-266.

133. Tot, Marko. E-learning in LIS education: satisfaction of part-time LIS students with Omega. // The Future of Information Sciences: INFuture2011: Information Sciences and e-Society / uredili Clive Billenness, Annette Hemera, Vladimir Mateljan, Mihaela Banek Zorica, Hrvoje Stančić i Sanja Seljan. Zagreb: Department of Information Sciences, Faculty of Humanities and Social Sciences, University of Zagreb, 2011. Str. 217-224. [citirano: 2018-10-02]. Dostupno na: http://infoz.ffzg.hr/INFuture/2011/papers/INFuture2011.pdf

2012.

134. Machala, Dijana. Knjižničarske kompetencije u Hrvatskoj u kontekstu cjeloživotnoga učenja: doktorska disertacija. Zagreb: Odsjek za informacijske znanosti, Filozofski fakultet Sveučilišta u Zagrebu, 2012.

135. Vujić, Žarka; Darko Babić. Education of museum and heritage educators in Croatia: history, organisation, quality. // Old questions, new answers : quality criteria for museum education / Željka Jelavić, Mila Škarić i Renata Brezinščak. Zagreb: ICOM CECA i Etnografski muzej u Zagrebu, 2012. Str. 19-26. 
2013.

136. Čičin-Šain, Marko; Slavomir Vukmirović; Marina Čičin-Šain. The strategic oriented information science education in the function of gaining strategic knowledge. // MIPRO, 2013: Proceedings of the 36th International Convention / uredio Petar Biljanović. Opatija: IEEE, 2013. Str. 922-927.

137. Hebrang Grgić, Ivana; Sonja Špiranec. Information Literacy of LIS students at the University of Zagreb: pros or just average millennials. // Worldwide Commonalities and Challenges in Information Literacy Research and Practice. Communications in Computer and Information Science / European Conference, ECIL 2013, Istanbul, Turkey, October 22-25, 2013.: Revised Selected Papers, vol. 397. / uredio Serap Kurbanoğlu, Esther Grassian, Diane Mizrachi, Ralph Catts i Sonja Špiranec. Springer, Cham, 2013. Str. 580-587.

138. Machala, Dijana; Aleksandra Horvat. Defining information literacy competences in a professional framework of library and information professionals in Croatia. // Worldwide Commonalities and Challenges in Information Literacy Research and Practice. ECIL 2013. Communications in Computer and Information Science, vol 397. / uredio Serap Kurbanoğlu. Cham; Heidelberg; New York; Dordrecht; London: Springer International Publishing Switzerland, 2013. Str. 639-646. DOI: https://doi.org/10.1007/978-3-31903919-0 86

139. Machala, Dijana. Stalno stručno usavršavanje knjižničara u Hrvatskoj: prigodom desete obljetnice osnutka Centra za stalno stručno usavršavanje knjižničara u Republici Hrvatskoj. // Vjesnik bibliotekara Hrvatske 56, 1/2(2013), 13-33. [citirano: 2018-10-02]. Dostupno na: https://hrcak.srce.hr/115091

140. Švenda-Radeljak, Ksenija. Obrazovanje i status knjižničara u Hrvatskoj do uvođenja studija bibliotekarstva: doktorska disertacija. Zagreb: Pravni fakultet Sveučilišta u Zagrebu, 2012.

141. Švenda-Radeljak, Ksenija. Doprinos Tatjane Blažeković profesionalnoj edukaciji hrvatskih knjižničara: ustroj i djelovanje Katedre za bibliotekarstvo na PA u Rijeci. // Knjižničar/ka 4, 4(2013), 21-41. [citirano: 2018-09-15]. Dostupno na: http://kdr.hr/wp-content/uploads/2017/01/Casopis-KDR-2013.pdf

142. Švenda-Radeljak, Ksenija. Stručno osposobljavanje hrvatskih knjižničara: od ideje do sveučilišnog studija. // 12. dani specijalnih i visokoškolskih knjižnica Knjižnice: kamo i kako dalje? = Libraries: where are we going?: zbornik sažetaka / uredila Vesna Špac. Zagreb: Hrvatsko knjižničarsko društvo, 2013. Str. 159-170.

2014.

143. Lasić-Lazić, Jadranka; Mihaela Banek Zorica; Sonja Špiranec. Obrazovanje školskih knjižničara temeljeno na ishodima učenja. // Informacijska tehnologija u obrazovanju / uredila Jadranka Lasić-Lazić. Zagreb: Zavod za informa- 
cijske studije, 2014. Str. 125-132. [citirano: 2018-10-02]. Dostupno na: https:// www.azoo.hr/images/izdanja/24_proljetna_skola_knjiznicara2012_web.pdf

144. Machala, Dijana; Irena Pilaš. Stalno stručno usavršavanje i novi koncepti: službene publikacije. // Međunarodni stručni skup Službene publikacije i državne informacije u knjižnicama Republike Hrvatske: zbornik radova / uredila Dunja Šverko Seiter. Zagreb: Nacionalna i sveučilišna knjižnica, 2014. Str. 155-172.

145. Machala, Dijana; Marko Orešković. Measuring information and digital literacy activities through learning record store repository of the national training centre for continuing education for librarians in Croatia. // Communications in Computer and Information Science / Second European Conference, ECIL 2014, Dubrovnik, Croatia, October 20-23, 2014.: Proceedings, vol. 492. / uredio Serap Kurbanoğlu. Springer, Cham, 2014. Str. 580-588.

146. Todorova, Tania; Tereza Trencheva; Serap Kurbanoğlu; Güleda Doğan; Aleksandra Horvat; Joumana Boustany. A multinational study on copyright literacy competencies of LIS professionals. // Communications in Computer and Information Science / Second European Conference, ECIL 2014, Dubrovnik, Croatia, October 20-23, 2014.: Proceedings, vol. 492. / uredili Serap Kurbanoğlu [et. al.]. Springer, Cham, 2014. Str. 138-148.

2015.

147. Aparac-Jelušić, Tatjana. The Convergence paradigm as the basis for the design of new programs in the field of the Information Sciences. // Annual Review of Cultural Heritage Informatics - ARCHI / uredila Jennifer Weil Arns. London: Facet, 2015. Str. 42-54. [citirano: 2018-10-02]. Dostupno na: https://satelliteturin2014.files.wordpress.com/2014/05/iflaltrsatellite2014_ aparac.pdf

148. Garić, Ana; Denis Kos; Hrvoje Stančić. Radionica o osnovnim metodama zaštite knjižnične građe i arhivskoga gradiva: primjer pedagoške aktivnosti za studente u arhivu. // 17. seminar „Arhivi, knjižnice, muzeji: mogućnosti suradnje u okruženju globalne informacijske infrastrukture "Globalno i lokalno, lokalno i globalno - glocal": zbornik radova / uredile Drahomira Cupar i Alisa Martek. Zagreb: Hrvatsko muzejsko društvo, 2015. Str. 324-326.

149. Hebrang Grgić, Ivana. Uloga nakladničke djelatnosti Hrvatskoga knjižničarskog društva u obrazovanju knjižničara. // Vjesnik bibliotekara Hrvatske 58, 1/2(2015), Str. 263-276. [citirano: 2018-10-02]. Dostupno na: https://hrcak. srce.hr/143634

150. Machala, Dijana. Knjižničarske kompetencije: pogled na razvoj profesije. Zagreb: Hrvatska sveučilišna naklada; Nacionalna i sveučilišna knjižnica u Zagrebu, 2015.

151. Machala, Dijana. Obrazovanje i stalno stručno usavršavanje knjižničara u kontekstu razvoja europskog knjižničarstva. // Očuvanje identiteta malih na- 
roda u Europskoj Uniji: pozicija i uloga knjižnica: zbornik radova: interdisciplinarni stručni skup / uredila Katarina Žužul Krolo. Split: Gradska knjižnica Marka Marulića, 2015. Str. 92-105.

2016.

152. Aparac-Jelušić, Tatjana. New approaches, structural and organizational changes in the PhD programme in LIS/IS.//Educating the profession: 40 years of the IFLA Section on education and training / uredili Michael Seadle i Clara M. Chu. Berlin; Boston: De Gryter Saur, 2016. Str. 68-83.

153. Aparac-Jelušić, Tatjana. Obrazovanje za digitalne knjižnice: pogled iz Europe. // Libellarium 9, 2(2016), 2-24. DOI: http://dx.doi.org/10.15291/libellarium.v9i2.289

154. Aparac-Jelušić, Tatjana. The challenge and obstacles of becoming an iSchool: the case of Zadar, Croatia. // Bulletin of the Association for Information Science and Technology 42, 4 (2016), 31-36. DOI: https://doi.org/10.1002/ bul2.2016.1720420409

155. Kolanović, Josip. Obrazovanje arhivista u Hrvatskoj. // Vizija i stvarnost: zbornik u povodu 40 godina djelovanja Aleksandre Horvat u knjižničarstvu / uredile Daniela Živković i Tatjana Nebesny. Zagreb: Hrvatska sveučilišna naklada, 2016. Str. 171-192. [citirano: 2018-10-02]. Dostupno na: https:// bib.irb.hr/datoteka/818867.Vizija_i_stvarnost_31.pdf

156. Mihalić, Marina. Pružanje knjižničnih usluga - razvoj kompetencija u sklopu Centra za stalno stručno usavršavanje knjižničara u Republici Hrvatskoj od 2002. do 2011. // Vizija i stvarnost: zbornik u povodu 40 godina djelovanja Aleksandre Horvat u knjižničarstvu / uredile Daniela Živković i Tatjana Nebesny. Zagreb: Hrvatska sveučilišna naklada, 2016. Str. 193-214. [citirano: 2018-10-02]. Dostupno na: https://bib.irb.hr/datoteka/818867.Vizija_i_ stvarnost_31.pdf

157. Tomić, Marijana; Marijana Majić-Mazul. Mogućnosti izobrazbe studenata informacijskih znanosti u području očuvanja kulturne baštine: prikaz projekta uređenja knjižnice samostana sv. Frane u Zadru. // Ogledi o informacijskim znanostima: zbornik radova u čast Tatjane Aparac Jelušić / uredile Sanjica Faletar Tanacković i Martina Dragija Ivanović. Osijek, Zadar: Sveučilište J. J. Strossmayera u Osijeku, Sveučilište u Zadru, 2016. Str. 48-56.

2017.

158. Stančić, Hrvoje. Obrazovanje arhivista. // Arhivi u Hrvatskoj - (retro)perspektiva / uredila Silvija Babić. Zadar: Hrvatsko arhivističko društvo, 2017. Str. 37-49.

159. Yordanova Todorova, Tania; Serap Kurbanoglu; Joumana Boustany, Güleda Dogan; Laura Saunders; Aleksandra Horvat; Ana Lúcia Terra; Ane Landøy; 
Angela Repanovici; Chris Morrison; Egbert J. Sanchez Vanderkast; Jane S ecker; Jurgita Rudzioniene; Terttu Kortelainen; Tibor Koltay. Information professionals and copyright literacy: A multinational study. // Library Management 38, 6/7(2017), 323-344.

2018.

160. Aparac-Jelušić, Tatjana; Sanjica Faletar Tanacković; Kornelija Petr Balog. Approach to harmonization of entry requirements for graduate program in information science at European higher institutions: EINFOSE project. // Proceedings of the Association for Library and Information Science Education Annual Project: ALISE 2018 / uredili Peiling Wang, Ashlea Green i Shimelis Assefa. Seattle: The Association for Library and Information Science Education (ALISE), 2018. Str. 6-10.

161. Čunović, Kristina; Alka Stropnik. The continuing professional development of school librarians in Croatia. // Global Action on School Library Education and Training. De Gruyter Saur, 2018. Str. 123-136.

162. Erl Šafar, Marija; Tihana Lubina. Formalno obrazovanje knjižničara: kratki povijesni pregled. // Vjesnik bibliotekara Hrvatske 61,1(2018), 219-239. [citirano: 2019-12-19]. Dostupno na: https://hrcak.srce.hr/206805

163. Kosić, Sanja; Sanja Hebrling Dragičević. Stručno usavršavanje knjižničara knjižničnog sustava Sveučilišta u Rijeci: stanje, mogućnosti, izazovi. // Vjesnik bibliotekara Hrvatske 61, 2 (2018), 305-324. DOI: https://doi. org/10.30754/vbh.61.2.699

164. Mučnjak, Dorja; Lisek, Jadranka. Mentori - okosnica praktične poduke studenata bibliotekarstva Filozofskog fakulteta u Zagrebu // Vjesnik bibliotekara Hrvatske, 61,2 (2018), 155-177. DOI: https://doi.org/10.30754/vbh.61.2.661

165. Švenda-Radeljak, Ksenija. Obrazovanje i status knjižničara u Hrvatskoj do uvođenja studija bibliotekarstva. Zagreb: Pravni fakultet Sveučilišta u Zagrebu, 2018.

166. Vrana, Radovan. Shaping the future information professionals: searching for the balance of job requirements in libraries and education. // 5th European Conference on Information Literacy in the Workplace, ECIL 2017, Saint Malo, France, September 18-21, 2017.: Revised Selected Papers, vol. 810 / uredili Serap Kurbanoğlu, Joumana Boustany, Sonja Špiranec, Esther Grassian, Diane Mizrachi i Loriene Roy. Springer, 2018. Str. 68-77.

2019.

167. Faletar Tanacković, Sanjica; Žilić, Jure; Panian Selimić, Maja. Znanstvenoistraživački rad i stalno stručno usavršavanje: percepcija hrvatskih knjižničara. // Vjesnik bibliotekara Hrvatske, 62, 1(2019), 49-76. DOI: https://doi. org/10.30754/vbh.62.1.710 
168. Filipeti, Antonija; Matilda Justinić; Dragana Koljenik. Continuing professional development of librarians in Croatia: participating in STEM revolution. // IFLA CPDWL Satellite meeting : Librarians and information professionals as (pro)motors of change: immersing, including and initiating digital transformation for smart societies, 2019. Str. 1-10. [citirano: 2020-01-24]. Dostupno na: http://library.ifla.org/2598/1/s05-2019-koljenik-en.pdf

169. Heđbeli, Živana. Zašto odabrati arhivistiku, zašto postati, biti i ostati arhivist/ica?. // Atlanti / uredili Peter Pavel Klasinc i Grazia Tato. Trieste, Maribor: State Archives of Trieste, International Institute for Archival Science of Trieste and Maribor, Amla mater Europeana - European Centr Mariborr, 2019. Str. 35-47.

170. Mučnjak, Dorja. A Mentor - from an inspirer to a friend: librarian mentoring programs in Croatia. // IFLA Satellite Meeting 2019 - Librarians and information professionals as (pro)motors of change: immersing, including and initiating digital transformation for smart societies. Zagreb, Hrvatska, 2019. Str. 1-9. [citirano: 2020-01-24]. Dostupno na: http://library.ifla.org/2601/1/ s05-2019-mucnjak-en.pdf

171. Švenda-Radeljak, Ksenija. Profesionalno okruženje i razvoj knjižničarske profesije u Hrvatskoj tijekom djelovanja Ljerke Markić-Čučuković // Kalibar 7, 2(2019), 29-33.

\section{Zaključak}

Bibliografijom je obuhvaćen 171 znanstveni i stručni rad hrvatskih autora o obrazovanju informacijskih stručnjaka u trima granama informacijskih i komunikacijskih znanosti - arhivistici i dokumentalistici, knjižničarstvu i muzeologiji. Kao što je vidljivo na slici 1 na kojoj je prikazan broj radova prema desetljeću njihova objavljivanja, znatan porast zabilježen je devedesetih godina 20. stoljeća. Nakon toga interes za tom problematikom nije jenjavao već je, štoviše, rastao. Dostupni podaci otkrivaju da je najveći broj radova (49 ili gotovo $29 \%$ ) obuhvaćenih ovom bibliografijom objavljen u prvom desetljeću 21. stoljeća, što tumačimo činjenicom da je upravo tada došlo do naglog razvoja informacijsko-komunikacijske tehnologije te se o njezinu implementiranju u studije informacijskih znanosti počelo ozbiljno promišljati. Vrijeme je to prilagodbe dotadašnjih „tradicionalnih“ programa potrebama i zadaćama novog vremena. Veliku je ulogu u porastu broja radova zasigurno imalo i uvođenje Bolonjskog procesa. U drugom desetljeću 21. stoljeća broj radova gotovo je jednak, što ukazuje na stalan interes za problematiku obrazovanja informacijskih stručnjaka. 


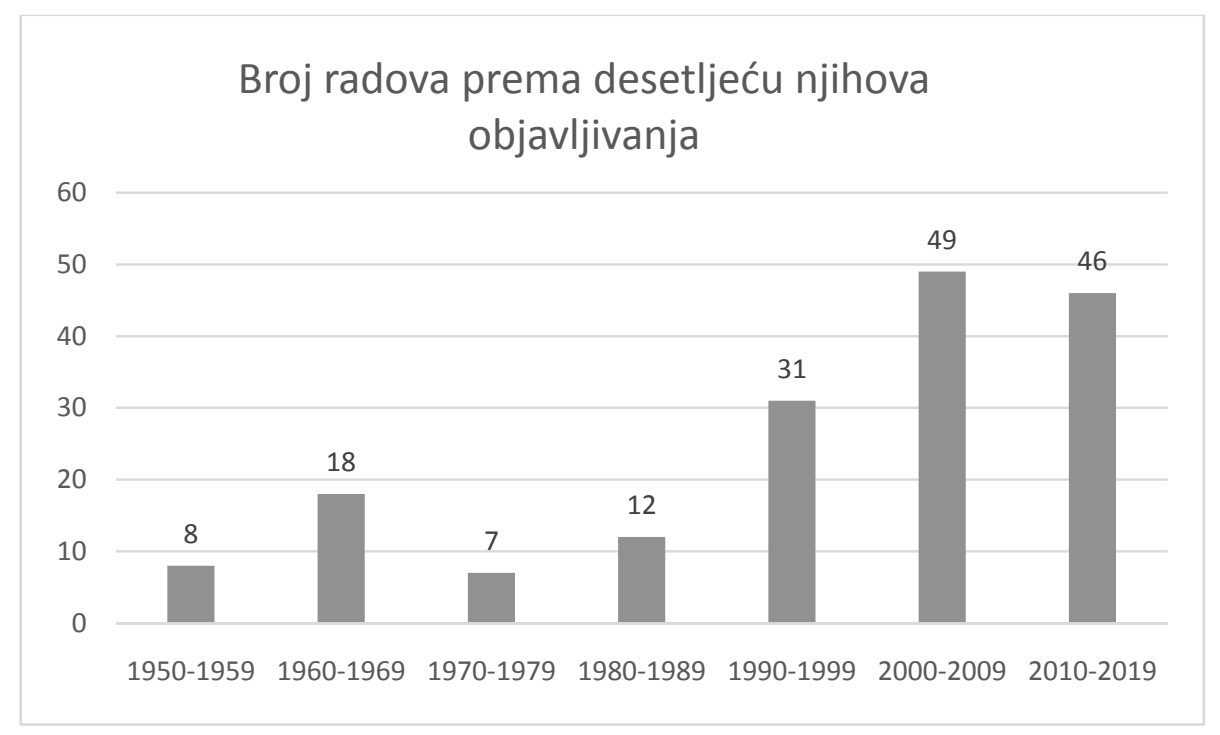

Slika 1. Broj radova prema desetljeću njihova objavljivanja

Bibliografske jedinice okupljene u ovoj bibliografiji ukazuju i na to da se o pitanju obrazovanja informacijskih stručnjaka u Hrvatskoj počelo promišljati još 1950-ih godina, upravo u vrijeme kada se polje informacijskih znanosti i počinje razvijati. Iz toga vremena datiraju prvi radovi koji su se, u vrijeme kada formalnog obrazovanja knjižničara i drugih informacijskih stručnjaka još nije niti bilo, uglavnom bavili tečajevima i seminarima kao neformalnim oblicima profesionalne edukacije. ${ }^{5}$ Sve do 1960 -ih godina tečajevi i seminari bili su vrlo praktičan oblik profesionalnog osposobljavanja, iako, dakako, nisu mogli nadomjestiti sustavno formalno školovanje. ${ }^{6}$ Neformalni oblici profesionalne edukacije knjižničara nastavili su biti u središtu zanimanja hrvatske stručne i znanstvene javnosti i 1960-ih godina, kada se broj radova udvostručava. Vrijeme je to i osnivanja poslijediplomskog studija bibliotekarstva, dokumentacije i informacijskih znanosti (1961.) na Prirodoslovnom fakultetu u Zagrebu, zaslugom Bože Težaka,

\footnotetext{
5 Začetke neformalne profesionalne edukacije, utemeljene uglavnom na praktičnom radu pod mentorstvom starijih kolega, međusobnoj razmjeni iskustava te konzultiranju inozemne stručne literature, bilježimo u okviru Kraljevske i sveučilišne knjižnice u Zagrebu, čijim osnivanjem 1874. godine započinje promišljanje o profesiji knjižničara, njihovu statusu i položaju u društvu. Tim će oblicima edukacije uskoro biti pridodani tečajevi i seminari, organizirani najčešće u okviru Sveučilišne knjižnice. O formalnom profesionalnom obrazovanju za knjižničare ozbiljnije se počelo promišljati i nakon Drugoga svjetskog rata. Usp. Švenda-Radeljak, K. Nav. dj., str. 22, 38-40, 63-69, 88, 94-109.

6 Isto, str. 282.
} 
„prvog i najvećeg hrvatskog klasika informacijskih znanosti“", ${ }^{7}$ čime hrvatsko knjižničarstvo napokon ulazi u sustav visokoškolskog obrazovanja. ${ }^{8}$ Tada se, zaslugom Tatjane Blažeković, također moglo, počevši s akademskom godinom 1964./1965., školovati za višeg knjižničara na Pedagoškom fakultetu u Rijeci. ${ }^{9}$ Međutim, razvoj formalnog fakultetskog obrazovanja knjižničara u Hrvatskoj, kojim se stjecalo zvanje diplomiranog knjižničara, započinje tek akademske godine 1975./1976., osnivanjem Katedre za bibliotekarstvo pri Odsjeku za komparativnu književnost na Filozofskom fakultetu u Zagrebu. ${ }^{10}$ Iako je to razdoblje bilo iznimno značajno u pogledu kontinuirane formalne edukacije knjižničara, začuđujuće, ono nije iznjedrilo veći broj radova. Veliki broj radova nije zabilježen niti u desetljeću koje slijedi. Međutim, zabilježena je značajna promjena u terminološkom, pa i u sadržajnom smislu, jer se već od početka 1980-ih godina bilježe radovi koji su se bavili tematikom obrazovanja muzealaca, „,bibliotečnih i ostalih informacijskih stručnjaka“, ${ }_{11}$ koji su problematizirali nastavni kurikulum tada još uvijek jedinog studija informacijskih znanosti, onog u Zagrebu, te raspravljali o uvođenju novih nastavnih sadržaja i problematizirali teorijsku jezgru informacijskih znanosti.

Početkom 1990-ih nastojala su se pratiti suvremena kretanja u obrazovanju informacijskih stručnjaka te se razvojem informacijskih tehnologija počela prepoznavati potreba za njihovim stalnim stručnim usavršavanjem. Izobrazba školskih knjižničara, modeli i oblici izobrazbe arhivista i njihov profesionalni identitet, izobrazba muzejskih stručnjaka, slobodan pristup informacijama u izobrazbi informacijskih stručnjaka, samo su neke od tema koje su bile predmet interesa hrvatskih stručnih i znanstvenih krugova. S aktualizacijom diskusije o konvergenciji disciplina unutar šireg područja informacijskih znanosti osamdesetih godina

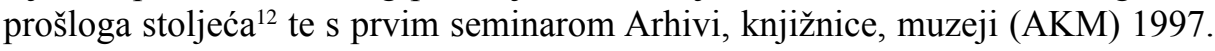
godine, koji je ,proizišao iz ideje o nužnosti otvaranja suradnje arhiva, knjižni-

\footnotetext{
7 Usp. Plenković, M. Božo Težak (1907-2007) - klasik informacijskih znanosti. // Informatologia 40, 1(2007), 20-31.

8 Usp. Švenda-Radeljak, K. Nav. dj., str. 109-112.

9 Isto, str. 112-121.

10 Isto, str. 121-124.

11 Aparac-Gazivoda, T.; A. Horvat. Dodiplomsko obrazovanje bibliotečnih i ostalih informacijskih stručnjaka. // Obrazovanje za tehnološki razvoj: savjetovanje. Zagreb: Savez inženjera i tehničara, 1985. Str. 181-188.

12 Takav smjer promišljanja o informacijskoj znanosti rezultat je okruženja globalnog informacijsko-komunikacijskog društva u kojem se, kako navodi Tatjana Aparac-Jelušić, ,pojedinačne discipline sve više zanimaju i za opća pitanja, tumače ih iz vlastita kuta gledanja, ali i očekuju da će njihovim djelotvornim prožimanjem jačati vlastitu znanstvenu osnovu i potvrđivati svoje mjesto u znanstvenoj obitelji.“ Aparac, T. Informacijske znanosti: temeljni koncepti i problemi. // Seminar Arhivi, knjižnice, muzeji. / uredile M. Willer et al. Zagreb: Hrvatsko bibliotekarsko društvo, 1998. Str. 15.
} 
ca i muzeja“"13 u uvjetima i okruženju nove, globalne informacijske infrastrukture, potaknuta su brojna pitanja vezana za zajednička i posebna znanja, vještine i kompetencije u stručnoj izobrazbi knjižničara, arhivista i muzeologa, odnosno za obrazovne programe u području informacijskih znanosti u odnosu na potrebe AKM zajednice. Problematika „obrazovanja informacijskih stručnjaka za globalni informacijski prostor"14 te njihova prilagodba „"novom' vremenu i promijenjenim zadaćama“, ${ }^{15}$ koja se nametnula nezaobilaznom početkom novog tisućljeća, ostat će sve do danas trajna stručna i znanstvena inspiracija nizu hrvatskih znanstvenika i stručnjaka u području informacijskih znanosti. U prvom se desetljeću 21. stoljeća otvaraju nove teme kao što su obrazovanje na daljinu, mobilnost studenata, online tečajevi, $e$-učenje, obrazovanje za digitalne knjižnice, a raspravlja se i o Bolonjskom procesu koji je, kao što znamo, na pragu novog tisućljeća počeo ulaziti na hrvatska sveučilišta. Otvaranjem Centra za stalno stručno usavršavanje knjižničara 2002. godine, cjeloživotno obrazovanje knjižničara postaje važna tema u stručno-znanstvenim interesima hrvatskih knjižničarskih znalaca, čemu je posvećena i doktorska disertacija Dijane Machale obranjena u području informacijskih i komunikacijskih znanosti 2012. godine. U posljednjem desetljeću obuhvaćenom ovim istraživanjem i dalje pronalazimo radove o obrazovanju studenata informacijskih znanosti za digitalne knjižnice ili u području očuvanja kulturne baštine, zatim radove o $e$-učenju i informacijskoj pismenosti studenata informacijskih znanosti, ali se ponajprije posebna pozornost pridaje problematici cjeloživotnog obrazovanja informacijskih stručnjaka.

Svakako su najzaslužniji i najprepoznatljiviji profesionalni znalci, koji su snažno pridonijeli rastu i razvoju informacijskih znanosti u Hrvatskoj te ostavili važan trag u nastavnom kurikulumu, Tatjana Aparac-Jelušić, Aleksandra Horvat, Jadranka Lasić-Lazić, Dijana Machala, Ivo Maroević i Aida Slavić, koji se pojavljuju s najvećim brojem stručnih i znanstvenih priloga, ali i mnogi drugi. Svakako ne treba izostaviti niti doajene hrvatskoga knjižničarstva, ali i cjelokupnog područja informacijskih znanosti kao što su Tatjana Blažeković, Višnja Vuković, Ljerka Markić-Čučković, Mira Mikačić, Matko Rojnić, Ivo Maroević i drugi, koji su ostavili trajan trag u području informacijskih znanosti, iako nisu zastupljeni s velikim brojem radova u području obrazovanja informacijskih stručnjaka.

Više od pola radova (102 ili gotovo $60 \%$ ) napisano je u suautorstvu dvoje ili više autora, kao što je vidljivo na slici 2, što upućuje na dobru profesionalnu

13 Willer, M. O AKM-u. [citirano: 2018-09-29]. Dostupno na: http://theta.ffzg.hr/akm/AKM_ ostali/o_akm.htm.

14 Lasić-Lazić, J.; A. Slavić. Obrazovanje informacijskih stručnjaka za globalni informacijski prostor. // Zbornik radova „Težakovi dani“ / uredili J. Lasić-Lazić i S. Tkalec. Zagreb: Filozofski fakultet, Zavod za informacijske studije Odsjeka za informacijske znanosti, 2002. Str. 151-158.

15 Lasić-Lazić, J.; A. Slavić. Školovanje knjižničara: kako prilagoditi „tradicionalne“ programe „novom vremenu“ i promijenjenim zadaćama. // Vjesnik bibliotekara Hrvatske 43, 4(2000), str. 59-69. 
suradnju hrvatske stručne i znanstvene zajednice koja se bavi problematikom obrazovanja informacijskih stručnjaka. Treba, međutim, reći da u počecima takve suradnje nije bilo jer se prvi rad napisan u suautorstvu pojavio tek 1981. godine, a nastao je u suradnji Matka Rojnića, hrvatskog knjižničara i dugogodišnjeg ravnatelja Nacionalne $i$ sveučilišne knjižnice u Zagrebu te slovenskog knjižničara Branka Berčiča, ravnatelja Narodne i univerzitetne knjižnice u Ljubljani. ${ }^{16} \mathrm{~S}$ vremenom njihov broj raste. Do kraja 1990-ih godina radovi su pisani uglavnom u suautorstvu nastavničkog kadra tada još uvijek jedinog studija na kojem se moglo dobiti formalno fakultetsko obrazovanje za knjižničara, onog u Zagrebu (Tatjana Aparac-Gazivoda, Aleksandra Horvat, Aida Slavić, Jadranka Lasić-Lazić, Radovan Vrana), kojima se kasnije pridružuju i zaposlenici dvaju novoosnovanih odsjeka za informacijske znanosti, u Osijeku i Zadru (Tatjana Aparac-Jelušić, Kornelija Petr Balog, Sanjica Faletar Tanacković, Martina Dragija Ivanović, Boris Badurina i drugi). Tek u proteklih desetak godina bilježimo i nekoliko radova napisanih u suautorstvu s inozemnim stručnjacima i znanstvenicima (Turska, Bugarska), što svjedoči o većoj otvorenosti domaće znanstvene i stručne javnosti prema inozemstvu te o njihovu uključivanju u suvremene tijekove razvoja područja informacijskih znanosti.

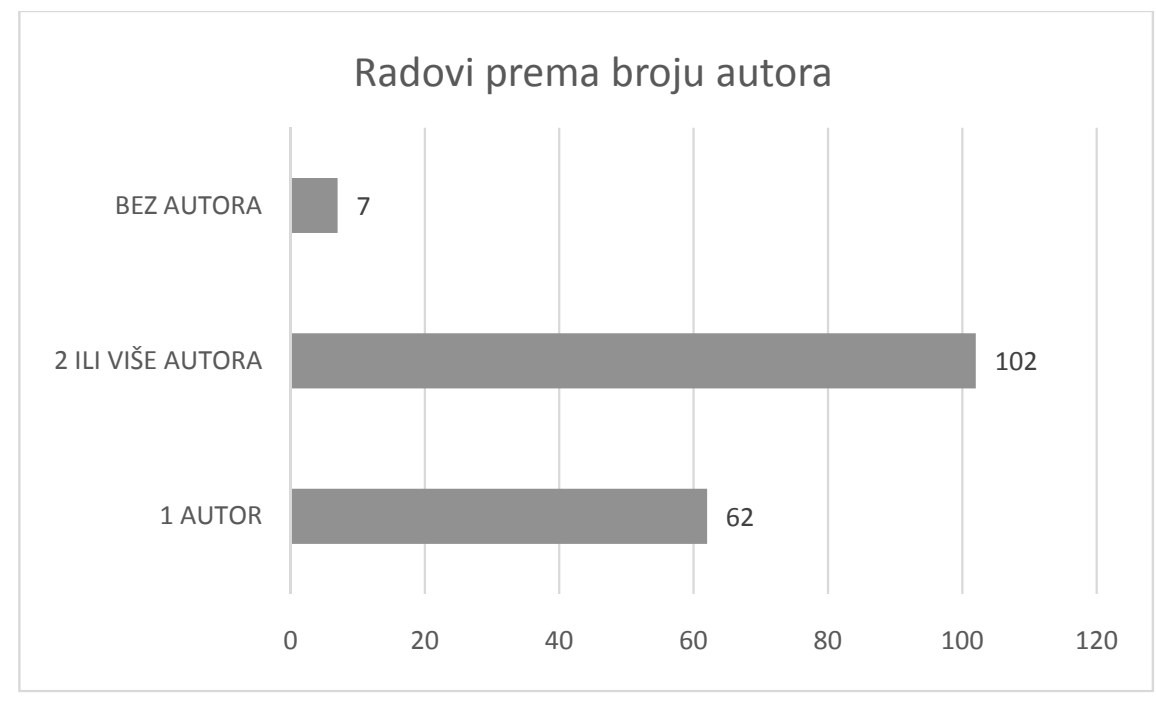

Slika 2. Radovi prema broju autora

Iako je najveći broj stručnih i znanstvenih radova objavljen u domaćim časopisima, njih 82 ili $48 \%$ (ponajprije u Vjesniku bibliotekara Hrvatske, ali i

16 Berčič, Branko; Matko Rojnić. Bibliotekarsko strokovno izobraževanje in mi : aktualno spominsko razmišljanje. // Vjesnik bibliotekara Hrvatske 1,1/4(1981), str. 11-18. 
u Arhivskom vjesniku, Knjižničarstvu, časopisu Život i škola, Informatologia, Informatica museologica, Edupointu, Organizaciji znanja, Libellariumu, Vukovarsko-srijemskom učitelju, Godišnjaku Gradske knjižnice i čitaonice Metel Ožegović, Knjižničar/ki, Radovima Pedagoške akademije u Rijeci, časopisu Kalibar), daleko je manji broj, i to tek većinom u dva protekla desetljeća obuhvaćena istraživanjem, objavljen i u stranim časopisima (Bibliotekar, Knjižnica, Bibliotekarska iskra, Pančevačko čitalište, ${ }^{17}$ New Library World, Information Research, Informacijos mokslai, IFLA SET Bulletin, Cataloging \& Classification Quarterly, Library Management, Museum Aktuell), kao što se može vidjeti na slici 3. Samo je 15 radova objavljenih u inozemnim časopisima, što čini oko $8 \%$ svih radova hrvatskih autora na temu obrazovanja informacijskih stručnjaka.

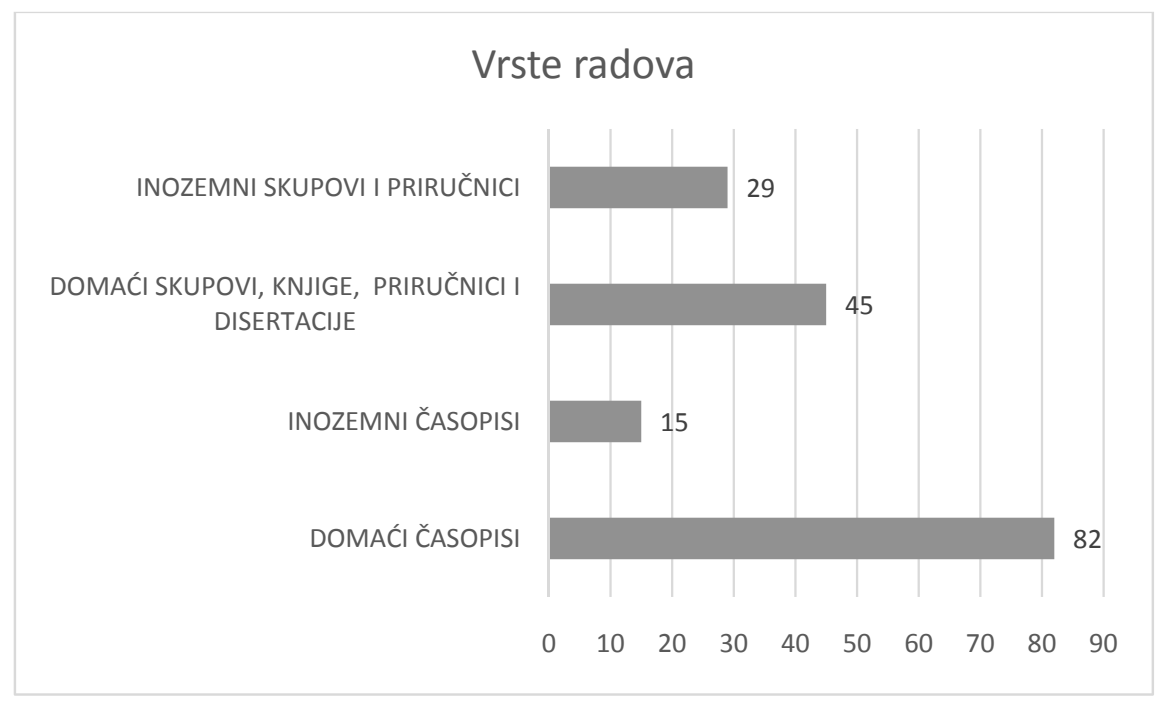

Slika 3. Vrste radova

Na slici 3 vidljivo je i da je relativno velik broj radova (74, odnosno $43 \%$ ) objavljen i u zbornicima dobro znanih domaćih i međunarodnih znanstvenih i stručnih skupova kao što su studentski Bobcatsss, seminar Arhivi, Knjižnice, Muzeji (AKM), Proljetna škola školskih knjižničara, Dani specijalnog i visokoškolskog knjižničarstva, MIPRO, skup Hrvatske udruge za informacijsku i komunikacijsku tehnologiju, elektroniku i mikroelektroniku, International Conference on Continuing Professional Education for the Library and Information Professions, The Future of Information Sciences (INFuture), EUCLID, skup European Asso-

17 Prva četiri časopisa - slovenska Knjižnica, srpski Bibliotekar i Pančevačko čitalište te makedonska Bibliotekarska iskra - svrstana su u kategoriju stranih časopisa, jer se u njima objavljivalo nakon raspada Jugoslavije, iako su neki od njih postojali i u vrijeme postojanja te države. 
ciation for Library \& Information Education and Research, European Conference on Information Literacy (ECIL), International Summer School of Museology (ISSOM), ali i mnogi drugi. Sudjelovanje ne samo na domaćim nego i na relevantnim inozemnim stručnim i znanstvenim skupovima ukazuje na značajan doprinos hrvatske znanstvene i stručne javnosti razumijevanju problematike obrazovanja informacijskih stručnjaka i na globalnoj razini. Jednako je to vidljivo i iz analize radova prema jezicima, koja je pokazala da je, uz radove na hrvatskom jeziku koji su u velikoj većini (123 ili $72 \%$ ), četvrtina njih objavljena na engleskom (44 ili 26 $\%$ ), dva na slovenskom te po jedan na njemačkom i makedonskom jeziku (slika 4). Radovi na engleskom jeziku pojavljuju se tek potkraj 1990-ih godina, nakon završetka Domovinskoga rata. Hrvatski znanstvenici i stručnjaci čiji se profesionalni interes kretao u okvirima problematike obrazovanja informacijskih stručnjaka postali su očito svjesni da je suradnja s inozemnim kolegama, na jeziku koji je u svijetu znanosti danas lingua franca, neophodna za razmjenu profesionalnih iskustava te razvoj cjelokupnoga područja.

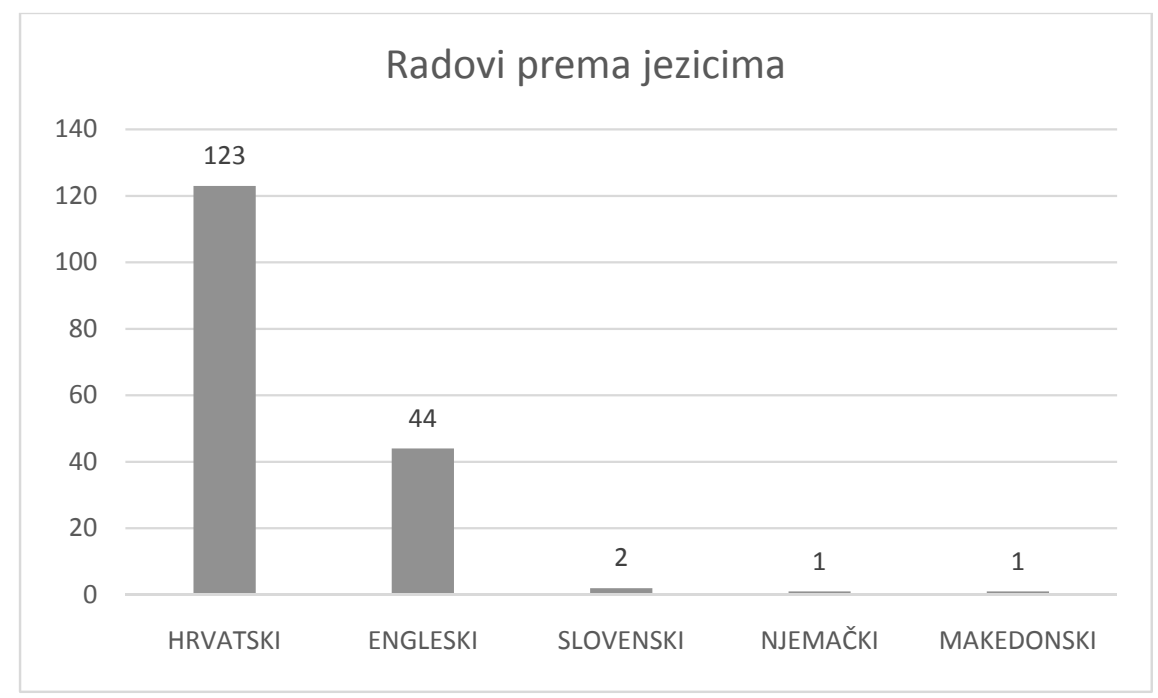

Slika 4. Radovi prema jezicima

Naposljetku, treba reći da je namjera ove bibliografije ukazati na to da je obrazovanje informacijskih stručnjaka od samih početaka razvoja informacijskih znanosti u nas prepoznato kao važan čimbenik koji utječe na prepoznatljivost struke i njezinu profesionalnu vjerodostojnost, o čemu svjedoči 171 rad njome obuhvaćen. Nadamo se da će promišljanja o obrazovanju informacijskih stručnjaka i o nužnosti njihova kontinuiranog stručnog usavršavanja koji su još od početka pedesetih godina 20. stoljeća zaokupljali brojne knjižničarske, muzejske i arhivske znalce, 
zaokupljati i nove generacije znanstvenika i stručnjaka, imajući u vidu neprestani napredak informacijsko-komunikacijske tehnologije koji nužno zahtijeva kontinuiranu prilagodbu.

\section{LITERATURA}

Aparac-Gazivoda, T.; A. Horvat. Dodiplomsko obrazovanje bibliotečnih i ostalih informacijskih stručnjaka. // Obrazovanje za tehnološki razvoj: savjetovanje. Zagreb: Savez inženjera i tehničara, 1985. Str. 181-188.

Aparac-Gazivoda, T. Teorijske osnove knjižnične znanosti. Zagreb: Filozofski fakultet, Zavod za informacijske studije Odsjeka za informacijske znanosti, 1993.

Aparac, T. Informacijske znanosti: temeljni koncepti i problemi. // Seminar Arhivi, knjižnice, muzeji / uredile M. Willer et al. Zagreb: Hrvatsko bibliotekarsko društvo, 1998. Str. 14-28.

Borko, H. Information science: what is it? // American Documentation 19, 1(1968), 3-5. [citirano: 2018-09-29]. Dostupno na http://jacksonmedeiros.files.wordpress. com/2008/08/information-science-what-is-it.pdf.

Ingwersen, P. Information and information science in context. // Libri 42, 2(1992), 99135.

Lasić-Lazić, J.; A. Slavić. Školovanje knjižničara: kako prilagoditi "tradicionalne" programe "novom vremenu" i promijenjenim zadaćama. // Vjesnik bibliotekara Hrvatske 43, 4(2000), 59-69.

Lasić-Lazić, J.; A. Slavić. Obrazovanje informacijskih stručnjaka za globalni informacijski prostor. // Zbornik radova „Težakovi dani“ / uredili Jadranka Lasić-Lazić i Slavko Tkalec. Zagreb: Filozofski fakultet, Zavod za informacijske studije Odsjeka za informacijske znanosti, 2002. Str. 151-158.

Maričić, S. Scientia Yugoslavica Bože Težaka. // Informatologia Yugoslavica 12, 3-4 (1980), 1-142.

Plenković, M. Božo Težak (1907-2007) - klasik informacijskih znanosti. // Informatologia 40, 1(2007), 20-31.

Pravilnik o znanstvenim i umjetničkim područjima, poljima i granama. // Narodne novine 118, 2929(2009). [citirano: 2018-09-29]. Dostupno na: https://narodne-novine. nn.hr/clanci/sluzbeni/2009_09_118_2929.html.

Rayward, W. B.. The history and historiography of information science: some reflections. // Information Processing \& Management 32, 1(1996), 3-17. DOI: http://citeseerx.ist.psu.edu/viewdoc/download?doi=10.1.1.136.1963\&rep=rep1\&type=pdf. 
Švenda-Radeljak, K. Obrazovanje i status knjižničara u Hrvatskoj do uvođenja studija bibliotekarstva. Zagreb: Pravni fakultet Sveučilišta, 2018.

Vakkari, P. Library and information science: its content and scope. // Advances in librarianship 18 (1994), 1-55.

Zins, C. Conceptions of information science. // Journal of the American Society for Information Science and Technology 58 , 3(2007), 335-350.

Zins, C. Knowledge map of information science. // Journal of the American Society for Information Science (JASIST) 58, 4(2007), 526-535.

Willer, M. O AKM-u. [citirano: 2018-09-29]. Dostupno na: http://theta.ffzg.hr/akm/ AKM_ostali/o_akm.htm. 